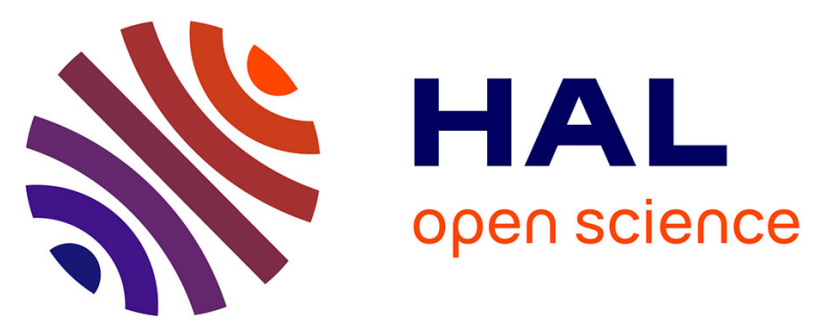

\title{
Evaluation of eroded mesozoic formations on Northern Alsace (France) using organic geochemistry and basin thermal modelling
}

Tchang-Tchong Laurie, Pierre Faure, Catherine Lorgeoux, Eric C. Gaucher, Raymond Michels

\section{To cite this version:}

Tchang-Tchong Laurie, Pierre Faure, Catherine Lorgeoux, Eric C. Gaucher, Raymond Michels. Evaluation of eroded mesozoic formations on Northern Alsace (France) using organic geochemistry and basin thermal modelling. 30th International meeting on Organic Geochemistry - IMOG 2021, Sep 2021, Online, France. hal-03429711

\section{HAL Id: hal-03429711 \\ https://hal.science/hal-03429711}

Submitted on 15 Nov 2021

HAL is a multi-disciplinary open access archive for the deposit and dissemination of scientific research documents, whether they are published or not. The documents may come from teaching and research institutions in France or abroad, or from public or private research centers.
L'archive ouverte pluridisciplinaire HAL, est destinée au dépôt et à la diffusion de documents scientifiques de niveau recherche, publiés ou non, émanant des établissements d'enseignement et de recherche français ou étrangers, des laboratoires publics ou privés. 
EVALUATION OF ERODED MESOZOIC FORMATIONS IN NORTHERN ALSACE (FRANCE) USING ORGANIC GEOCHEMISTRY AND BASIN THERMAL MODELLING

\author{
L. Tchang-Tchong ${ }^{1,2}$, P. Faure-Catteloin ${ }^{2}$, C. Lorgeoux ${ }^{1}$, E. C. Gaucher ${ }^{3}$, R. Michels ${ }^{1}$ \\ ${ }^{1}$ Université de Lorraine, CNRS, GeoRessources lab, UMR 7359, France \\ ${ }^{2}$ Université de Lorraine, CNRS, LIEC lab, UMR 7360, France \\ ${ }^{3}$ TOTAL SA, CSTJF, 64000 Pau, France
}

\title{
Introduction
}

The Upper Rhine Graben (URG) is a Cenozoic intracontinental rift, which extends partly in France, Germany and Switzerland, $300 \mathrm{~km}$ long and 30-40 km wide (Schumacher, 2002). The sedimentary basin is NNE/SW trending and its current geometry corresponds to a set of asymmetrical and antithetical halfgraben, connected by transfer zones using structures inherited from the Paleozoic. Pre-rift sedimentary filling is composed of a serie of Triassic to Middle Jurassic formations separated from syn-rift Cenozoic deposits by a major unconformity. While the Mesozoic sediments are very similar to those encountered in the Paris Basin, the Cenozoic deposits are typical of the URG. The study area corresponds to the Pechelbronn sub-basin which which holds most of the petroleum reservoirs of northern Alsace (France), in the western central part of the URG.

In the Pechelbronn sub-basin, as elsewhere in the URG, it is noticed that the unconformity reaches the Middle Jurassic formations. Compared to the Paris Basin sedimentary successions, this questions why Upper Jurassic and Cretaceous formations are missing (Schnaebele, 1948; Ménillet et al., 2015). Especially for the Cretaceous sediments, it remains uncertain whether their absence is related to a sedimentary hiatus or a period of intense erosion as discussed by Ziegler (1990) or Blaise et al. (2011, 2014). This uncertainty is problematic to rebuild the burial history of Mesozoic sedimentary formations. Indeed, vitrinite reflectance values (Ro\%) in well profiles present a sharp offset in Ro\% values in the Jurassic series compared to the Tertiary (Robert, 1985) suggesting that there may be two different geothermal histories to be considered.

Rock samples of Tertiary and Jurassic ages as well as petroleum samples were collected in the Pechelbronn area and analysed for their organic geochemistry. The geochemical analyses of the Jurassic outcrops show that the Mesozoic formations are immature or in the early oil window. If we consider that the pre-tertiary sedimentary column was not sufficiently buried before the Cretaceous, we can estimate a maximum paleo-burial and thus, evaluate the thickness of the eroded series. This estimation is made using 1D thermal models (PetroMod) from wells located in the Northern Alsace for which geological and Ro\% data were published (Robert, 1985).

The aim of this presentation will be to show evaluation of heat flux, oil generation and maximum paleo-burial in the Pechelbronn area by using molecular markers, vitrinite reflectance, kinetic properties of source-rocks and artificial maturation. The comparison between the values simulated by the 1D thermal basin models (PetroMod) and the measured values from the maturity markers allows calibration for these wells. Model calibration consists in estimating the thicknesses of the eroded series and heat flux values. Supplementary information are brought by comparing calculated thermal maturity of oils with geochemistry of collected oil samples. Special attention will be given to possible local heat anomalies linked 
to hydrothermal fluid circulations, well known in the URG (Werner and Doebl, 1974; Lampe and Person, 2002; Baillieux, 2012).

This work is funded by DEEPSURF project "Lorraine Université d'Excellence", ANR-15IDEX-04-LUE.

\section{References}

Baillieux, P. (2012). Multidisciplinary approach to understand the localization of geothermal anomalies in the Upper Rhine Graben from regional to local scale (Doctoral dissertation, Université de Neuchâtel).

Blaise, T., Izart, A., Michels, R., Suarez-Ruiz, I., Cathelineau, M., Landrein, P. (2011). Vertical and lateral changes in organic matter from the Mesozoic, eastern Paris Basin (France): Variability of sources and burial history. International journal of coal geology, 88(2-3), 163 178.

Blaise, T., Barbarand, J., Kars, M., Ploquin, F., Aubourg, C., Brigaud, B., Cathelineau, M., El Albani, A., Gautheron, C., Izart, A., Janots, D., Michels, R., Pagel, M., Pozzi, J.-P., Boiron, M.-C., Landrein, P. (2014). Reconstruction of low temperature $\left(<100^{\circ} \mathrm{C}\right)$ burial in sedimentary basins: A comparison of geothermometer in the intracontinental Paris Basin. Marine and Petroleum Geology, 53, 71-87.

Lampe, C., \& Person, M. (2002). Active cooling within sedimentary rift basins-application to the Upper Rhine Graben (Germany). Marine and Petroleum Geology, 19(3), 361-375.

Ménillet, F., Durand, M., Genter, A., Party, J. P. (2015). Notice explicative de la carte géologique de France (1/50000). Feuille Haguenau (198) (2éd.).

Robert, P. (1985). Histoire géothermique et diagenèse organique. Null. Centr. Rech. Explor. Prod. ELF-Aquitaine. Mém. 8, 345 pp., Pau.

Schnaebele, R. (1948). Monographie géologique du champ pétrolifère de Pechelbronn. Mém. Serv. Carte géol. Als. Als. Lorr. 7, 254 p.

Schumacher, M. E. (2002). Upper Rhine Graben: role of preexisting structures during rift evolution. Tectonics, 21(1), 6-1.

Werner, D., \& Doebl, F. (1974). Geothermal anomalies and consequences for diagenesis and thermal waters. Approaches to Taphrogenesis. Schweizerbart, Stuttgart, 182-191.

Ziegler, P. A. (1990). Collision related intra-plate compression deformations in Western and Central Europe. Journal of Geodynamics, 11(4), 357-388. 